\title{
Research knowledge in undergraduate school in Brazil: a comparison between medical and law students
}

\author{
Conhecimento científico na graduação do Brasil: \\ comparação entre estudantes de Medicina e Direito
}

\author{
Antonio José Souza Reis Filho¹, Bruno Bezerril Andrade², Vitor Rosa Ramos de Mendonça ${ }^{3}$, Manoel Barral-Netto ${ }^{4}$
}

\begin{abstract}
Objective: Exposure to science education during college may affect a student's profile, and research experience may be associated with better professional performance. We hypothesized that the impact of research experience obtained during graduate study differs among professional curricula and among graduate courses. Methods: A validated multiple-choice questionnaire concerning scientific concepts was given to students in the first and fourth years of medical and law school at a public Brazilian educational institution. Results: Medical students participated more frequently in introductory scientific programs than law students, and this trend increased from the first to the fourth years of study. In both curricula, fourth-year students displayed a higher percentage of correct answers than first-year students. A higher proportion of fourth-year students correctly defined the concepts of scientific hypothesis and scientific theory. In the areas of interpretation and writing of scientific papers, fourth-year students, in both curricula, felt more confident than first-year students. Although medical students felt less confident in planning and conducting research projects than law students, they were more involved in research activities. Conclusion: Medical graduation seems to favor the development of critical scientific maturity than law graduation. Specific policy in medical schools is a reasonable explanation for medical students' participation in more scientific activities.
\end{abstract}

Keywords: Research; Education, medical, undergraduate; Students, medical

\section{RESUMO}

Objetivo: $\mathrm{A}$ exposição à educação científica durante a faculdade pode afetar o perfil do estudante, e a experiência na pesquisa pode estar associada com um melhor desempenho profissional.
Hipotetizamos que 0 impacto da experiência na pesquisa obtida durante a graduação varia entre os currículos profissionais e entre os cursos de graduação. Métodos: Um questionário validado de múltipla escolha sobre conceitos científicos foi dado aos alunos do primeiro e quarto anos das faculdades de Medicina e Direito em uma instituição pública brasileira de ensino. Resultados: 0s estudantes de Medicina participaram com mais frequência de programas de iniciação científica em relação aos estudantes de Direito, e essa tendência aumentou do primeiro ao quarto ano de faculdade. Em ambos os currículos, os alunos do quarto ano apresentaram uma maior porcentagem de acertos que os alunos do primeiro ano. A maior proporção de alunos do quarto ano definiu corretamente os conceitos de hipótese científica e teoria científica. Nas áreas de interpretação e escrita de artigos científicos, os alunos do quarto ano, em ambos os currículos, se sentiram mais confiantes do que os estudantes do primeiro ano. Embora os estudantes de Medicina tenham se sentido menos confiantes no planejamento e na realização de projetos de pesquisa que os estudantes de Direito, eles estavam mais envolvidos em atividades de pesquisa. Conclusão: A graduação em Medicina parece favorecer o desenvolvimento da maturidade crítica científica do que a graduação em Direito. A existência de políticas específicas nas escolas médicas é uma explicação razoável para a participação de estudantes de Medicina em mais atividades científicas.

Descritores: Pesquisa; Educação de graduação em Medicina; Estudantes de Medicina

\section{INTRODUCTION}

Scientific reasoning is a necessary element in professional education. Furthermore, research publications have a direct effect on changing clinical practices. Therefore,

\footnotetext{
Study carried out at Universidade Federal da Bahia - UFBA, Salvador (BA), Brazil.

${ }^{1}$ Medical student; Scientific Methodology student of Centro de Pesquisas Gonçalo Moniz of Fundação Oswaldo Cruz - FIOCRUZ, Salvador (BA), Brazil.

${ }^{2} \mathrm{MD}$; PhD of Laboratory of Parasitic Diseases - NIH, Bethesda (MD), United States.

${ }^{3}$ Medical student; Scientific Methodology student of Centro de Pesquisas Gonçalo Moniz of Fundação Oswaldo Cruz - FIOCRUZ, Salvador (BA), Brazil.

${ }^{4}$ Full researcher of Centro de Pesquisas Gonçalo Moniz of Fundação Oswaldo Cruz - FIOCRUZ, Salvador (BA), Brazil.

Corresponding author: Manoel Barral-Netto - Rua Waldemar Falcão, 121 - Candeal - CEP 40296-710 - Salvador (BA), Brasil - Tel.: 71 3176-2259 - E-mail: mbarral@bahia.fiocruz.br

Received: Mar 27, 2010 - Accepted: Jul 15, 2010

We affirm that there is no commercial conflict of interests among the authors of the present manuscript.
} 
exposure to high quality scientific work may be an effective way to improve Public Health, particularly in developing countries ${ }^{(1)}$. Research experience may develop students' skills in independent learning, critical assessment of medical literature, and writing scientific papers ${ }^{(2)}$. If such experience is not provided, the result may be a lack of basic research capabilities, thus hampering these abilities and leading to the production of professionals who are less inclined to think as they practice $^{(3)}$ - a factor that, among other social and economic conditions, could be associated with low quality in medical care. Considering all this, it becomes obvious that significant changes in the Public Health system will only be achieved by means of substantial reforms in the educational processes in which the professionals that compose this system participate ${ }^{(4)}$.

The extent of engagement in research on a dayto-day professional basis is likely to vary among professional careers. Exposure to science during graduate study depends on the type of school one attends. Historically, medical graduate programs teach critical approaches to scientific methods, as these programs are responsible for most of the universities' scientific production ${ }^{(5)}$. Despite strong efforts to encourage the practice of Medicine based on scientific evidence, medical curricula have been criticized recently as increasingly technical, and this has lead to a devaluation of scientific careers. As a result, following a worldwide trend ${ }^{(6,7)}$, innovative curriculum changes have been proposed and implemented in Brazilian medical colleges. Given that the study of law - as a social subject - approaches science differently, it encourages and enriches the comparison of law and medical curricula. In the former, exposure to research and scientific methods is expected to have a less direct impact on student's education, as the reasoning used in this discipline is subject to societal influences, besides those based on medical and scientific research. However, certain areas of the law curriculum, such as forensic Medicine, are directly and strongly impacted by scientific progress.

The scientific initiation program, a national Brazilian project, encourages graduate students to participate in research activities in all areas of study. Over 19 thousand fellowships are granted annually to graduate students, enabling them to spend part of their time during their graduate career working on research projects under faculty supervision. This program provides opportunities for students to participate in research activities under various curricula ${ }^{(8)}$. We took advantage of the opportunity provided by this program to compare the responses of first- and fourthyear law and medical students to scientific questions to assess whether scientific development is specific to medical school curricula or whether such development constitutes a general university trend.

\section{METHODS}

\section{Study design and participants}

A cross-sectional study was conducted among firstand fourth-year students enrolled in the medical and law schools at the Universidade Federal da Bahia (UFBA), a public university in Salvador (BA), Brazil. At least two reasons can be named to justify the choice of these courses. First, the different rationales involved in each discipline make law an appropriate reference for measuring the impact of medical science instruction. The second reason is the high academic skills that an average law or medical student must possess in order to enroll in a Brazilian public university. A questionnaire adapted from Khan et al. ${ }^{(9)}$ was given by a trained graduate student to all first-year students $(\mathrm{n}=80)$ and all fourth-year students $(\mathrm{n}=80)$ in the medical school. The questionnaire was also given to 40 of the 80 first-year students $(\mathrm{n}=40)$ and to all fourth-year students $(\mathrm{n}=80)$ in the law school. After a written consent, the students were told to answer the questionnaire anonymously, and their responses were de-indentified. "First-year students" actually refers to undergraduates in their first year in college. The questionnaire was distributed to students during their regular classes; after obtaining the consent, they were asked to return the answered copies 30 minutes later. Response rates were 72.5 and $65 \%$ among first- and fourth-year medical students (M1 and M4), respectively, and 92.5 and $86.2 \%$ among firstand fourth-year law students (L1 and L4), respectively. After being approved by the chair of the Department of Pathology of UFBA, the research protocol received fast track approval by the head of the IRB of the Centro de Pesquisas Gonçalo Moniz of Fundação Oswaldo Cruz, Salvador (BA), Brazil.

\section{Questionnaire}

The questionnaire was organized into sections, each addressing a specific topic. One section was composed of multiple-choice questions regarding basic scientific concepts, knowledge of statistics and identification of parts of a scientific paper. Another section was composed of survey questions concerning interpretation and writing of scientific papers, as well as planning and conducting research projects. The questionnaire also covered demographic characteristics, including the student's age and gender, as well as information about his or her participation in introductory scientific 
programs. The questionnaire used is reproduced in the supplemental material (Appendix 1).

\section{Data analysis}

All data were analyzed anonymously. Three relative contrasts were of particular interest: M1 x L1, a comparison between medical and law students with respect to their characteristics at admission (baseline characteristics); M1 x M4 and L1 x L4, to assess the acquisition of scientific knowledge within each graduate course (as assessed by multiple-choice questions); and M4 x L4, to analyze students' profiles at the end of each graduate course (as assessed by survey questions). For the multiple-choice questions, results were plotted as a percentage of correct answers, and the differences were analyzed by Fisher's exact test. The same methodology was used to compare baseline characteristics between groups. The total score of each group was calculated as the mean percentage \pm standard deviation (SD) of correct answers to multiple-choice questions and was analyzed using the Kruskal-Wallis test with Dunn's multiple comparisons. For survey questions, results were shown as frequencies of occurrence of each possible answer, and the differences were analyzed using $\chi^{2}$ test. GraphPad Prism ${ }^{\circledR} 5.0$ software was used to analyze the data. $\mathrm{P}<0.05$ was considered statistically significant.

\section{RESULTS}

\section{Baseline characteristics}

The majority of the evaluated students were male; this was similar among the four groups (Table 1). Fourthyear students of both courses were also similar in age $(82.7 \%$ M4 versus $84.1 \%$ L4 students were over 21 years old; $p=1)$. Generally, medical students are younger than law students when they enter graduate school, with $96.6 \%$ of M1 students being under 21 years versus $75.7 \%$ of L1 students ( $p<0.005)$. Medical students were significantly more active in introductory scientific programs than law students, and this scientific participation increased with time spent in college $(30.8 \%$ M4 versus $2.9 \%$ L4 or $6.9 \%$ M1 students, $\mathrm{p}<0.0001$ and $\mathrm{p}<0.005$, respectively). This time-dependent increase did not occur among students in law school (Table 1).

\section{Performance in total score}

A section of the questionnaire was composed of multiple-choice questions. The total score of each group was calculated as the mean percentage of correct answers given to these questions. As seen in Figure 1A, the proportional mean score of correct answers
Table 1. Baseline characteristics of the students enrolled

\begin{tabular}{|c|c|c|c|c|c|}
\hline \multirow{2}{*}{\multicolumn{2}{|c|}{$\begin{array}{l}\text { Baseline } \\
\text { characteristics }\end{array}$}} & $\begin{array}{c}M 1 \\
n=58\end{array}$ & $\begin{array}{c}\text { L1 } \\
n=37\end{array}$ & $\begin{array}{c}M 4 \\
n=52 \\
\end{array}$ & $\begin{array}{c}L 4 \\
n=69\end{array}$ \\
\hline & & \multicolumn{4}{|c|}{ n (\%) } \\
\hline Gender & Male & 34 (58.6) & $20(54.1)$ & $29(55.8)$ & $35(50.7)$ \\
\hline \multirow[t]{2}{*}{ Age (years) } & $\leq 21$ & $56(96.6)^{*}$ & $28(75.7)^{*}$ & $9(17.3)$ & $11(15.9)$ \\
\hline & $>21$ & $2(3.4)$ & $9(24.3)$ & $43(82.7)$ & 58 (84.1) \\
\hline $\begin{array}{l}\text { Participated in } \\
\text { introductory } \\
\text { scientific program }\end{array}$ & & $4(6.9)^{\dagger}$ & - & $16(30.8)^{t, \pm}$ & $2(2.9)^{\ddagger}$ \\
\hline
\end{tabular}

Gender, age and engagement in introductory scientific programs of all students are shown as n (\%). M1: first-year medical students; M4: fourth-year medical students; L1: first-year law students; L4: fourth-year law students. Frequencies between fourth- and first-year students from both courses of study and between matched groups (M1x L1 and M4 x L4) were compared by Fisher's exact test. A p-value of $<0.05$ was considered significant. ${ }^{*} p<0.005 ; \dagger p<0.005 ; \neq p<0.0001$.
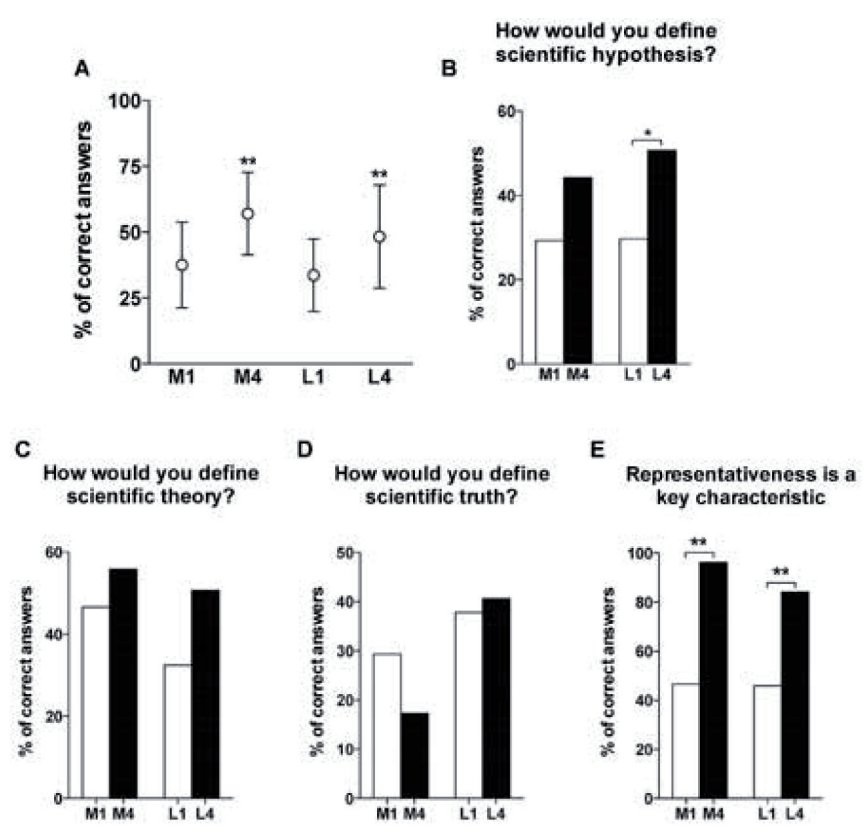

A: General performance of the students enrolled. Values are shown as the mean percentage \pm SD of correct answers to multiple-choice questions for each group. The Kruskal-Wallis test with Dunn's multiple comparison

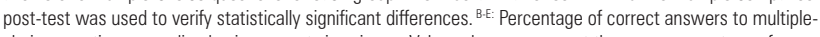
choice questions regarding basic concepts in science. Values shown represent the mean percentage of correct answers from students. Fisher's exact test was used to evaluate differences between fourth and first-year students from both graduating courses. M1: first-year medical students; M4: fourth-year medical students; L1: first-year law students; L4: fourth-year law students.

${ }^{*} p<0.05 ;{ }^{* *} p<0.001$.

Figure 1 - Percentages of correct answers to multiple-choice questions

obtained from fourth-year students was higher than that of the first-year students (group mean $\pm \mathrm{SD}$, M4 $57 \pm 15.7$ versus M1 $37.5 \pm 16.2 ; \mathrm{p}<0.005$ and L4 48.3 \pm 19.6 versus L1 $33.6 \pm 13.7 ; \mathrm{p}<0.005)$. There were no differences between matched students (M1 versus L1 or M4 versus L4).

\section{Theoretical concepts in science}

Four multiple-choice questions were intended to evaluate students' understanding of basic concepts in general science. For the most part, fourth-year students defined "scientific hypothesis" correctly more often than the first-year students, although this difference was statistically significant only between the two law 
student groups (Figure 1B, M4 44.2\% versus M1 29.3\%; L4 $50.7 \%$ versus L1 29.7\%; $p=0.04)$. Nevertheless, despite the higher percentage of correct answers regarding the definition of "scientific theory" among fourth-year students, the observed difference did not achieve statistical significance for either courses of study (Figure 1C, M4 55.8\% versus M1 46.6\%; L4 50.7\% versus $\mathrm{L} 132.4 \% ; \mathrm{p}=0.34$ and $\mathrm{p}=0.1$, respectively). Surprisingly, fourth-year medical students displayed poorer average performance in defining "scientific truth" than first-year students, although, again, this disparity was not significant (Figure 1D, M4 17.3\% versus M1 29.3\%; $p=0.18$ ). Furthermore, there was no statistical difference between the performances of firstand fourth-year law students (Figure 1D, L4 40.6\% versus $\mathrm{L} 137.8 \%$; $\mathrm{p}=0.84)$. The last question of the basic concepts section assessed knowledge of research, which holds representativeness as a key characteristic. Once more, fourth-year students performed better than the first-year students; in this case, the difference between first- and fourth-year students in both courses was significant (Figure 1E, M4 96.2\% versus M1 46.6\%; $p<0.0001$; L4 84.1\% versus L1 45.9\%; $p<0.0001$ ). Therefore, fourth-year students in both medical and law graduate courses showed a better grasp of basic science concepts than the first-year students.

\section{Practical concepts in science}

When asked about the essential characteristic of science, the students from both graduate courses showed an unsatisfactory performance; the maximum percentage of correct answers did not exceed $35 \%$ in any studied group (Figure 2A). Nevertheless, noteworthy and significant improvement over time was observed in both courses of study (Figure 2A, M4 34.6\% versus M1 15.5\%; $\mathrm{p}=0.03$; L4 29\% versus L1 10.8\%; $\mathrm{p}=0.05$ ). Furthermore, it was requested that the students indicate what constitutes the basic structure of a scientific paper. Interestingly, only medical students showed improvement over time in their responses to this question (Figure $2 \mathrm{~B}, \mathrm{M} 446.2 \%$ versus M1 22.4\%; $p=0.01$; L4 15.9\% versus L1 16.2\%; $p=1$ ). According to these data, graduate courses contributed to the acquisition of more solid practical concepts in science, and this effect was more striking in students of medical school.

\section{Handling of research articles and projects}

The last part of the questionnaire aimed to analyze the graduate students' easiness in handling scientific articles and projects. Possible answers were presented as a scale representing degrees of confidence: "no", if the student
A

Essential characteristic of science
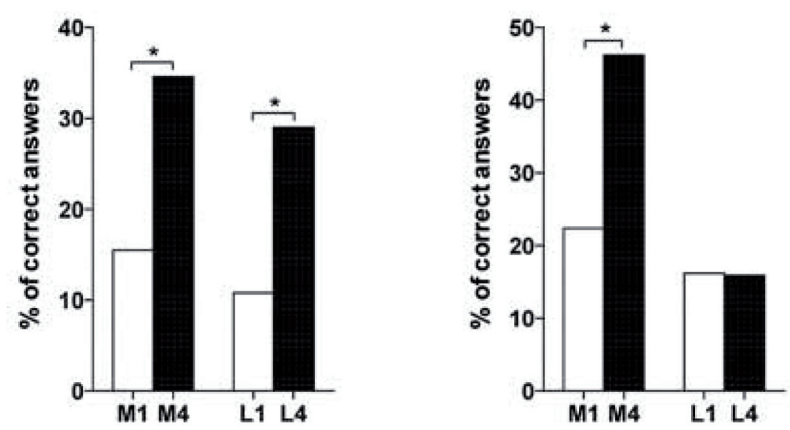

Values shown represent the mean percentage of correct answers from students. M1: first-year medical students; M4: fourth-year medical students; L1: first-year law students; L4: fourth-year law students. Fisher's exact test was used to evaluate differences between fourth- and first-year students from both courses of study. ${ }^{*} p<0.05$.

Figure 2 - Percentages of correct answers among multiple-choice questions regarding practical concepts in science

did not feel confident; "yes, with assistance", if he or she did not feel fully confident; and "yes", if he or she felt completely confident. As seen in Figure 2, fourth-year students felt more confident in interpreting a scientific paper than the first-year students ("yes": M4 78.8\% versus M1 17.2\%; L4 62.3\% versus L1 10.8\%; p < 0.0001). In addition, medical students exhibited more confidence in interpreting a scientific paper than law students ("yes": $78.8 \%$ versus L4 62.3\%; $p<0.0001)$. Concerning writing a scientific paper, although fourth-year students felt more confident than the first-year students ("yes, with assistance": M4 84.6\% versus M1 46.6\%; L4 $63.7 \%$ versus L1 54.1\%; $\mathrm{p}<0.0001$ ), law students felt more confident in writing a scientific paper by themselves than medical students ("yes": L4 23.2\% versus M4 7.7\%; $\mathrm{p}<0.0001$ ). Moreover, law students expressed greater confidence than medical students with regard to writing a scientific paper without assistance, although the difference was not statistically significant ("yes": L4 $17.4 \%$ versus M4 $5.8 \%$ ). Furthermore, although medical students felt less confident in planning and conducting a research project than law students ("yes": M4 5.8\% vesus L4 13\% and "yes": M4 3.8\% versus L4 11.6\%, respectively), they were less likely to be involved in research projects (Figure 3, M4 78.8\% versus L4 20.3\%).

\section{DISCUSSION}

Professionals in any field of knowledge need to master the concepts of scientific research. Students who know the concepts and goals of science are more secure and confident in interpreting professional literature, even if they do not intend to become producers of scientific knowledge. Hence, a solid professional foundation benefits from participation in research activities and 


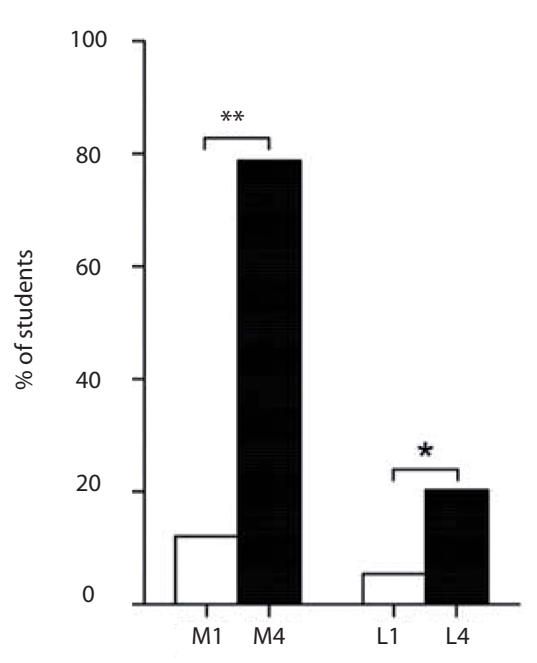

Values shown represent percentages of students. M1: first-year medical students; M4: fourth-year medical students; L1: first-year law students; L4: fourth-year law students. Fisher's exact test was used to evaluate differences between fourth- and first-year students from both courses of study.

${ }^{*} p<0.05$; ** $p<0.001$.

Figure 3 - Percentages of students who confirmed that they had participated in research projects

from exposure to the scientific method in place of an early professionalization.

In the past few years, universities have given special attention to the scientific training of its students. Research curricula were instituted with many (often unspecified) goals in mind, including the increasing knowledge of critical appraisal and the process of research, stimulating intellectual curiosity, increasing willingness to be involved in research, increasing the ability to conduct research, developing a higher degree of clinical proficiency and critical thinking, and uncovering early academic career interests ${ }^{(10)}$.

Medical students begin college, on average, at an earlier age than law students (Table 1), and this may be associated with less scientific maturity, leading to less satisfactory development of critical assessment skills and the production of fewer innovative scientific ideas. However, during the first year in college, medical students were already more active in searching for introductory scientific programs, and they were more involved in research projects as well (Figure 3 ). This finding suggests that first-year students in medicine and law exhibit different profiles regarding their scientific interests. Personality traits contributing to such differences in interests may influence students' choice of career. Medical curricula may strengthen students' previously existing scientific interests, since a remarkable increase in science-related activities occurred only during graduate study. Consistent with this finding, the School of Medicine of UFBA is associated with higher levels of scientific production than any other graduate school, including the Law School ${ }^{(5)}$ of this university.
Despite these differences, law students achieved results similar to those of medical students with respect to the average number of correct answers given to multiple-choice questions (Figure 1A). Therefore, because there was a statistically significant improvement between first- and fourth-year students from both courses of study, it seems that progression through either medical or law school can stimulate scientific maturity. Together, these data reveal the influence of graduate courses on scientific development.

Students with research experience published more papers after graduate school than those who had no such experience ${ }^{(11)}$. Even more importantly, research experiences may affect professional performance by enabling an individual to change and adapt, improving practice outcomes $^{(12)}$.

In general, fourth-year students' performances were better than those of the first-year students regarding both theoretical and practical concepts in science (Figures 1 and 2, respectively). However, medical and law students diverged with respect to skills, probably due to specific trends in each curriculum. While law students displayed better performance on questions about theoretical scientific concepts, medical students showed superior understanding of practical scientific concepts. Two particular comparisons illustrate this disparity: in the question "How you would define the scientific hypothesis", only the answers from first- and fourth-year law students showed statistically significant differences (Figure 1B). Conversely, only medical school students displayed any improvement in recognition of a part of a scientific paper (Figure 2B). Thus, medical and law schools' distinct profiles may contribute to the development of specific characteristics. Of particular interest was the unexpectedly poor performance of fourth-year medical students in defining the term "scientific truth". The majority defined it as a truth that will be reached by means of scientific research, while a consensus of competent experts was the appropriate answer. By graduation, the definition of scientific truths as a consensus among experts seems to be more obvious to law students. They apparently realized that such truths are summarized in the propositions of a given area's specialists and that empirical proof of these truths is often impossible to obtain. On the other hand, medical students seem more accustomed to the practical experience of scientific research due to the specific needs of their course. Perhaps the practical experience gained during medical coursework causes students to overestimate the significance of scientific methodology and does not involve the student in all stages of scientific production. In support of this idea is the result that medical students displayed more confidence 
in interpreting a scientific paper than law students. However, medical students were less sure about writing a scientific paper compared to law students (Table 2). Thus, although medical students gain experience and confidence in their ability to interpret scientific literature, a lack of writing experience is evident upon their graduation. Medical students surveyed in the present report studied under a Lecture Based Learning (LBL) curriculum, and it has been shown that Problem Based Learning (PBL) leads to more confidence in conducting research and writing scientific papers, as this method encourages independent learning ${ }^{(13)}$.

Nevertheless, fourth-year students in both courses felt more capable of interpreting and writing a scientific paper by themselves than those just entering college, demonstrating that graduate school may stimulate students' self-confidence, although in a limited degree. However, this improvement was not observed with regard to the idea of planning and conducting a research project, demonstrating once again the partial achievement of students in understanding the scientific process. It should be pointed out in this context that, for students, research is often understood to be mainly technical, without requirements for participation in study design or critical reflection on its processing methods ${ }^{(4)}$. To some extent, this may reflect insufficient time dedicated to research activities, as the medical curricula are very demanding of time, or this partial scientific achievement may reflect inadequate mentoring. Additionally, expectations of low salary compensation in research could deter medical students from pursuing scientific careers; thus, by graduation they are not dedicating much time to research and might tend to shift their focus to clinical interests ${ }^{(2)}$.
All these aspects combined may limit the recruitment of potential scientists who, otherwise, could be identified in their positive scientific experiences during their graduate studies $^{(11)}$.

It is essential to stimulate critical thinking and reasoning skills, developing a positive attitude amongst students towards scientific research from the beginning of their medical career ${ }^{(11)}$. Encouraging and motivating student research could make up for the lack of physician scientists and help developing countries achieve selfreliance in Health care and research ${ }^{(14)}$. One of the limitations of this study is also one of its most enriching aspects: the marked differences involving the areas of study in Medicine and Law. Medicine, in this context, has a more solid scientific basis that is grounded in the traditional paradigm of the natural sciences and, therefore, is more guided by scientific rigor and accuracy of data. In contrast, Law has a broader range of possible interpretations; the parameter of objectivity is not the only one guiding research.

However, despite epistemological differences, in both areas the importance of scientific experience in the transition from passive knowledge and thoughtless practice to the stage of active wisdom and critical exercise of one's profession have been observed. After all, a proper sense of the general elements of scientific research - including knowledge of expressions -, the ability to write or interpret a scientific article and conduct scientific research can be seen as tools, if well used, for producing excellent results.

Students in both Medicine and Law courses displayed a high degree of development in understanding theoretical and practical scientific concepts over time,

Table 2. Undergraduate students' easiness to handle scientific articles and projects

\begin{tabular}{|c|c|c|c|c|c|c|}
\hline \multirow[t]{2}{*}{ Student's confidence } & & $\begin{array}{c}\mathrm{M} 1 \\
\mathrm{n}=58\end{array}$ & $\begin{array}{c}\mathrm{L1} \\
\mathrm{n}=37\end{array}$ & $\begin{array}{c}\text { M4 } \\
n=52\end{array}$ & $\begin{array}{c}\text { L4 } \\
n=69\end{array}$ & \multirow{2}{*}{$\begin{array}{c}\chi^{2}- \\
\mathbf{p} \text { value }\end{array}$} \\
\hline & & \multicolumn{4}{|c|}{ n (\%) } & \\
\hline \multirow[t]{3}{*}{ Do you feel confident in interpreting a research paper? } & No & $10(17.2)$ & $5(13.5)$ & $1(1.9)$ & $4(5.8)$ & $p<0.0001$ \\
\hline & Yes, with assistance & $38(65.5)$ & $28(75.7)$ & $10(19.2)$ & $22(31.9)$ & \\
\hline & Yes & $10(17.2)$ & $4(10.8)$ & $41(78.8)$ & $43(62.3)$ & \\
\hline \multirow[t]{3}{*}{ Do you feel confident in writing a research paper? } & No & $30(51.7)$ & $17(45.9)$ & $4(7.7)$ & $9(13)$ & $p<0.0001$ \\
\hline & Yes, with assistance & $27(46.6)$ & $20(54.1)$ & $44(84.6)$ & $44(63.7)$ & \\
\hline & Yes & $1(1.7)$ & - & $4(7.7)$ & $16(23.2)$ & \\
\hline \multirow{3}{*}{$\begin{array}{l}\text { Do you think undergraduate students can write a scientific } \\
\text { paper? }\end{array}$} & No & $1(1.7)$ & $1(2.7)$ & $1(1.9)$ & $3(4.3)$ & ns \\
\hline & Yes, with assistance & 50 (86.2) & 31 (83.8) & $48(92.3)$ & $54(78.2)$ & \\
\hline & Yes & $7(12.1)$ & $5(13.5)$ & $3(5.8)$ & $12(17.4)$ & \\
\hline \multirow{3}{*}{$\begin{array}{l}\text { Do you think undergraduate students can plan a research } \\
\text { project? }\end{array}$} & No & - & - & $2(3.8)$ & $5(7.2)$ & ns \\
\hline & Yes, with assistance & $52(89.7)$ & $33(89.2)$ & 47 (90.3) & 55 (79.7) & \\
\hline & Yes & $6(10.3)$ & $4(10.8)$ & $3(5.8)$ & $9(13)$ & \\
\hline \multirow{3}{*}{$\begin{array}{l}\text { Do you think undergraduate students can conduct a research } \\
\text { project? }\end{array}$} & No & $4(6.9)$ & - & $3(5.8)$ & $10(14.5)$ & ns \\
\hline & Yes, with assistance & 50 (86.2) & 33 (89.2) & $47(90.4)$ & 51 (73.9) & \\
\hline & Yes & $4(6.9)$ & $4(10.8)$ & $2(3.8)$ & $8(11.6)$ & \\
\hline
\end{tabular}

Undergraduate students' opinion on interpretation, reading and writing of scientific article, as well as on planning and conducting a research project are displayed as $n$ (\%). Possible answers were constructed on a scale representing degree of confidence: "no", if they do not feel confident; "yes, with assistance", if they do not feel fully confident; "yes", if they feel completely confident. M1: first-year medical students; M4: fourth-year medical students; L1: first-year law students; L4: fourth-year law students. Frequencies were compared by $\chi^{2}$ test. A $p$-value of $<0.05$ was considered significant. ns: not significant. 
which shows the influence of university training in this process. This observed effect was stronger among medical school students and may be explained by their exposure to more scientific activities related to this purpose. The orientation of specific policies toward science is the basis of the emphasis observed in the study of Medicine.

\section{CONCLUSIONS}

Medical graduation seems to favor the development of critical scientific maturity than law graduation. Specific policy in medical schools is a reasonable explanation for medical students' participation in scientific activities.

\section{ACKNOWLEDGEMENTS}

The authors thank all the students who participated in this study, as well as the professors who kindly provided extra time in their classes for administration of the questionnaire. We are grateful to Dr. H. Khan for kindly making available the questionnaire used in his previous publication.

\section{REFERENCES}

1. Page J, Heller RF, Kinlay S, Lim LL, Qian W, Suping Z, et al. Attitudes of developing world physicians to where medical research is performed and reported. BMC Public Health. 2003;3:6.

2. Aslam F, Shakir M, Qayyum MA. Why medical students are crucial to the future of research in South Asia. PLoS Med. 2005;2(11):e322.
3. O'Connor JP, Kanga DR. Academic medicine: time for reinvention: medical education, training, and research are under threat because academic medicine is undervalued. BMJ. 2004;328(7430):45-6.

4. Dandona L. Academic medicine: time for reinvention: public health sciences need strengthening in developing countries. BMJ. 2004;328(7430):47.

5. Barral A, Barral-Netto M. A Faculdade de Medicina da Bahia e a Ciência Médica. Gazeta Médica da Bahia. 2008;78(Suppl 1):117-20.

6. Custers EJ, Cate OT. Medical students' attitudes towards and perception of the basic sciences: a comparison between students in the old and the new curriculum at the University Medical Center Utrecht, The Netherlands. Med Educ. 2002;36(12):1142-50.

7. Kaufman DM, Mann KV. Basic sciences in problem-based learning and conventional curricula: students' attitudes. Med Educ. 1997;31(3):177-80.

8. Conselho Nacional de Desenvolvimento Científico e Tecnológico (CNPq). Programa Institucional de Bolsas de Iniciação Científica (PIBIC). Quotas aprovadas para o período 2008/2009 [Internet]. 2008 [cited 2009 Sept 12]. Available from: http://www.cnpq.br/programas/pibic/docs/quota_08_09. pdf

9. Khan H, Khawaja MR, Waheed A, Rauf MA, Fatmi Z. Knowledge and attitudes about health research amongst a group of Pakistani medical students. BMC Med Educ. 2006;6:54.

10. Smith M. Research in residency: do research curricula impact post-residency practice? Fam Med. 2005;37(5):322-7.

11. Reinders JJ, Kropmans TJ, Cohen-Schotanus J. Extracurricular research experience of medical students and their scientific output after graduation. Med Educ. 2005;39(2):237.

12. Chen FM, Bauchner $H$, Burstin $H$. A call for outcomes research in medical education. Acad Med. 2004;79(10):955-60.

13. Khan $H$, Taqui AM, Khawaja MR, Fatmi Z. Problem-based versus conventional curricula: influence on knowledge and attitudes of medical students towards health research. PLoS One. 2007;2(7):e632.

14. Scaria V. Whisking research into medical curriculum: the need to integrate research in undergraduate medical education to meet the future challenges [editorial]. Calicut Medical Journal. 2004;2(1):e1. 
Appendix 1 - Scientific research and graduating students

This questionnaire was designed to investigate the knowledge on basic science concepts and in scientific research of graduating students in Bahia, Brazil.

Please, answer the questionnaire below if you would like to participate. Your contribution may be important for future basement on administrative and academic decisions concerning this subject. All personal information provided will be confidential and your identity will be preserved, as you do not need to sign this form. We appreciate your cooperation.

Please, check only one answer for each question.

Course: $\square$ FAMEB-UFBA $\square$ Medicine-FBDC $\square$ Medicine-FTC

$$
\text { Age (years): } \begin{gathered}
\square<18 \text { years } \square 18-21 \square 22-25 \text { years } \square 26 \text {-30 years } \\
\square>30 \text { years }
\end{gathered}
$$

Gender: $\square$ Male $\square$ Female

$$
\text { Year in college: } \square 1^{\text {st }} \square 2^{\text {nd }} \square 3^{\text {rd }} \square 4^{\text {th }} \square 5^{\text {th }} \square 6^{\text {th }}
$$

Have you ever participated in any activity related to scientific research in college?

$\square$ Yes $\square$ No

If affirmative, check below which activities you have done:

$\square$ Introductory scientific programs

Time spent: $\square<6$ months $\square 6$ m-1year $\square>1$ year.

Type of scholarship: $\square$ PIBIC $\square$ Other

$\square$ Voluntary trainee

Time spent: $\square<6$ months $\square 6$ m-1year $\square>1$ year.

$\square$ Teacher assistance

Time spent: $\square<6$ months $\square 6$ m-1year $\square>1$ year.

$\square$ Other activities

Describe:

01) How would you define SCIENTIFIC HYPOTHESIS?

$\square$ A proposed idea or thought

$\square$ An answer or solution to a question

$\square$ An answer or solution to a question that can be empirically verified or demonstrated

$\square$ Logical deduction of premises that may or may not be verified empirically

\section{2) How would you define SCIENTIFIC THEORY?}

$\square$ Speculation or assumption with none or insufficient evidence

$\square$ Scientific hypothesis that may be proved but lacks evidences for its verification

$\square$ Set of scientific knowledge on a given topic or area

$\square$ System of hypotheses logically connected to one another, with common background, some of which have been verified

\section{3) How would you define SCIENTIFIC TRUTH?}

$\square$ Truth that will be reached through scientific research

$\square$ Absolute truth

$\square$ Consensus of competent experts

$\square$ Fact that can be found in the textbooks

$\square$ Facts that your professors teach you

04) Essential characteristic of science:

$\square$ All scientific conclusions are temporary

$\square$ Scientific theory can not merely explain natural phenomena, but must somehow also exert influence upon them

$\square$ Obvious scientific conclusions do not have to be tested

$\square$ An experiment is not an objective model of nature, but serves as an introduction into real research of natural phenomena

$\square$ Some natural phenomena do not have to be measured; their identification by an investigator is enough
05) A 1 to 5 scale (as the marks of an exam) is called:

$\square$ Ratio scale

$\square$ Nominal

$\square$ Ordinal

$\square$ Interval

$\square$ It is not a scale

06) Representativeness is a key characteristic of:

$\square$ Scientific paper with original data

$\square$ Meta-analysis paper

$\square$ Scientific research

$\square$ Sample

$\square$ Population

\section{7) MEDLINE is}

$\square$ The first and best known online medical journal

$\square$ International Association of Medical Informatics

$\square$ The printed version of the Medical Encyclopedia of scientific papers

$\square$ Acronym that enumerates the parts of a researched paper

$\square$ Medical database

08) Part of a scientific paper:

$\square$ Author's curriculum vitae.

$\square$ Letter to the editor enclosed with the paper.

$\square$ Description of the timeline.

$\square$ Acknowledgment to persons who assisted you during the research

09) All the rules below are applied for the writing of the INTRODUCTION section of a scientific paper, EXCEPT:

$\square$ To indicate clearly the reason to begin the research

$\square$ It should not explain the data of textbooks

$\square$ It should not explain the words of the title

$\square$ It should be extensive instead of summarized

$\square$ To define clearly the problem of the research that needs an answer

010) Do you feel confident in interpreting a research paper?

$\square$ No $\square$ Yes, with assistance $\square$ Yes, without assistance

011) Do you feel confident in writing a research paper?

$\square$ No $\square$ Yes, with assistance $\square$ Yes, without assistance

012) Do you think undergraduate students can write a scientific paper?

$\square$ No $\square$ Yes, with assistance $\square$ Yes, without assistance

013) Have you ever written a scientific paper?

$\square$ Yes $\square \mathrm{No}$

014) Do you think undergraduate students can plan a research project? $\square$ No $\square$ Yes, with assistance $\square$ Yes, without assistance

015) Do you think undergraduate students can conduct a research project?

$\square$ No $\square$ Yes, with assistance $\square$ Yes, without assistance

016) Do you think undergraduate students should participate in scientific research?

$\square$ Yes $\square$ No

017) Have you ever participated in research projects? (apart from mandatory academic ones)

$\square$ Yes $\square$ No 